\title{
COMPUTER AIDED DESIGN OF POLYGALACTURONASE II FROM ASPERGILLUS NIGER
}

IBRAHIM Ali NOORBATCHA, NUR IZZAH ISMAIL AND HAMZAH MOHD. SALLEH

Bioprocess and Molecular Engineering Research Unit, Department of Biotechnology Engineering, Kulliyyah of Engineering, International Islamic University Malaysia, Jalan Gombak 53100 Kuala Lumpur, Malaysia.

ibrahiman@iium.edu.my

\begin{abstract}
Pectin is a complex polysaccharide found in the cell walls of plants and consisting mainly of esterified D-galacturonic acid resides in $\alpha$-(1-4) chain. In production of fruit juice, pectin contributes to fruit juice viscosity, thereby reducing the juice production and increasing the filtration time. Polygalacturonase improves the juice production process by rapid degradation of pectin. In this project we have designed a novel polygalacturonase enzyme using computer aided design approaches. The three dimension structure of polygalacturonase is first modeled on the basis of the known crystal structure. The active site in this enzyme is identified by manual and automated docking methods. Lamarckian genetic algorithm is used for automated docking and the active site is validated by comparing with existing experimental data. This is followed by in silico mutations of the enzymes and the automated docking process is repeated using the mutant enzymes. The strength of the binding of the ligands inside the active site is evaluated by computing the binding score using Potential Mean Force (PMF) method. The in silico mutations R256Q and $\mathrm{K} 258 \mathrm{~N}$ are found to decrease the binding strength of the ligand at the active site, indicating lowering of enzyme activity, which is consistent with the experimental results. Hence in silico mutations can be used to design new polygalacturonase enzymes with improved enzyme activity.
\end{abstract}

ABSTRAK: Pektin adalah polisakarida kompleks yang terdapat di dalam dinding sel tumbuhan dan sebahagian besarnya terdiri daripada asid D-galakturonik terester yang ditemui di dalam rantaian $\alpha-(1-4)$. Dalam penghasilan jus buah-buahan, pektin menyumbang dalam kepekatan jus buah-buahan, di mana ia mengurangkan penghasilan jus dan menambahkan masa penapisan. Poligalakturonase meningkatkan proses penghasilan jus dengan pemecahan pektin dengan cepat. Dalam projek ini, kami telah merangka satu enzim poligalakturonase baru dengan menggunakan pendekatan reka bentuk berbantukan komputer. Struktur tiga dimensi poligalakturonase ini pada permulaannya dimodelkan berasaskan kepada struktur kristal. Tapak aktif enzim ini dikenali pasti dengan kaedah mengedok manual dan automatik. Algoritma genetik Lamarckian digunakan untuk dok berautomatik dan tapak aktif ini disahkan dengan perbandingan dengan data eksperimental yang sedia ada. Kaedah ini diikuti pula dengan mutasi in siliko enzim dan proses mengedok automatik diulangi dengan menggunakan enzim mutan. Kekuatan ikatan ligan yang berada di dalam tapak aktif dinilai dengan mengira kiraan ikatan menggunakan kaedah Min Keupayaan Daya (Potential Mean Force $(P M F)$ ). Mutasi in siliko R256Q dan K258N merupakan penyebabpenurunan dalam kekuatan ikatan ligan di tapak aktif, menunjukkan pengurangan dalam aktiviti enzim, di mana ianya konsisten dengan keputusan ekperimental. Jesteru, mutasi siliko boleh digunakan untuk mereka enzim poligalakturonase baru dengan mempertingkatkan aktiviti enzim. 
KEYWORDS: computer aided design; polygalacturonase; automated docking; in silico mutations

\section{INTRODUCTION}

Enzymes are natural catalyst which permits endogenous biological reaction to occur rapidly through well-defined pathway. They occur in almost all creatures ranging from the simple microorganism to well defined complex human beings [1]. Most enzymes are much larger than the substrates that they are acting on and only a small portion of enzymes is directly involved in the catalysis. The region that contains these catalytic residues, binds the substrate, and then carries out the reaction is known as the active site. Enzyme's activity can be affected by reaction time, amount of enzyme, temperature, substrate concentration, $\mathrm{pH}$, ionic strength, pressure, and inducers and inhibitors [2].

Pectins are very complex and heterogeneous molecules which are regular ingredient of all higher plant (Table 1). Pectins build the cell walls together with cellulose and hemicelluloses; therefore contribute to cell wall functions [3]. Pectin molecules have a linear backbone composed of units of $(1,4)$-linked $\alpha$-D-galacturonic acid and its methyl ester. Pectin contents are specific to fruit species. Pectins are primary cause of juice viscosity.

Table 1: Pectin content of some fruits.

\begin{tabular}{lc}
\hline Fruit & Pectin content, w\% \\
\hline Apple & $0.5-1.6$ \\
Blackcurrant & $1.0-1.2$ \\
Grape & $0.1-0.4$ \\
Orange peel & $3.5-5.5$ \\
Pear & $0.7-0.9$ \\
Pineapple & $0.04-0.1$ \\
Strawberry & $0.5-0.7$ \\
\hline
\end{tabular}

Polygalacturonases are the enzymes that cleavage the $\alpha$-1,4-glycosidic linkage of polygalacturonic acid chains by hydrolysis and release oligogalacturonides. Thus, they are involved in pectin degradation. They are classified as the family 28 of glycosyl hydrolase based on amino acid sequences similarity. Normally, the common source of producing these enzymes is the filamentous fungus Aspergillus sp. Sometimes, they also can be obtained from tomatoes and oranges. In addition, moulds are used frequently for commercial preparation of polygalacturonases because of the high pectolytic activities exhibited by member of the genera. Polygalacturonase is a major component of industrial pectinases [4]. It is widely used in fruit processing industry because it produces more rapid depolymerization. Polygalacturonases have heavy demand in fruit juice industry due to its activity that degraded the pectin and reduce the viscosity of juice produced. According to Nikolic and Mojovic [3], $50 \%$ of overall viscosity is reduced for the initial $9 \%$ hydrolysis of substrate in degradation of apple pectin by polygalacturonases.

Molecular modeling is defined as a simplified or idealized description of a system to mimic the behavior of the molecule and molecular system [5]. Molecular modeling helps in understanding more about protein, enzyme and structures. The objectives of this project 
are to analyze the structure of polygalacturonase and model the active site that involved in enzyme activity. In addition, this model will help to suggest the modification to A. niger Polygalacturonase II to achieve the desired activity, that is better degrading of pectin.

\section{METHODOLOGY}

\subsection{Acqcuiring Crystal Structure}

The crystal polygalacturonase from Aspergillus niger (PGII) by accession number 1CZF was obtained from Protein Data Bank (PDB: www.rcsb.org/pdb) that is maintained by the Research Collaboratory for Structural Bioinformatics (RCSB).

\subsection{Cleaning the structure}

The bonding in HET groups were checked and corrected, then the hydrogen atoms are added and the atom hybridization is defined.

\subsection{Visualizing Protein}

The process started with atom definition, proceeds with hydrogen bonds displaying, protein sequences viewing, coloring and ends with labeling. All the mentioned steps are very crucial and foundation steps for enzyme modification. By following these steps, a clear picture about the structure of the enzyme can be obtained.

\subsection{Analyzing the Active Site}

Conceptually, active site is the lowest energy region in the structure which contains catalytic residues that will react with the ligand. The active site region of PGII-1CZF was identified according to the information given in the literature. All the residues around that particular region can be recognized. The active site location is studied through accessible surfaces to observe the nature of the active site in terms of hyrophobicity and hydrophilicity areas and crevice surface able to pin point ideal location on the active site where potential binding was possible.

For confirmation of the active site, the comparison has been made between the PGII and other structure with the ligand in the structure. The docked ligand into the PGII structure and the location of ligand was compared.

Before enzyme modification, the possible candidates was examined or screened to make sure they pose the similar traits of physical and chemical properties that are near the current ligand. The study of currently available ligand leads the information in choosing the best candidates for modification.

\subsection{Docking with Hexagalacturonide 1 (HGA1)}

The docking process was conducted by genetic algorithm docking. An identified ligand was docked onto the active site region. The parameters used in automated docking using Lamarkian genetic algorithm are shown in Table 2. Then, the docked position was adjusted to fit well the enzyme structure and the evaluation process started. The binding energy depends upon the number of hydrogen bonds and other interaction between the ligand and protein.

Docking model used in this study assumes that the protein and ligand dock noncovalently. It is assumed that bonds are not formed between the ligand and protein because bond formation would cause changes in the atom types and possible substantial changes in the shape of the ligand and the active site. The active bound site box set at $35 \AA$, to ensure enough space is available for the ligand to be docked. 


\subsection{Single Point Mutation}

Simulated single point mutation was done on the amino acid residues in the conserved region and other residues of the enzyme by substituted amino acids randomly within $5 \AA$ from the ligand. It was done to determine the significance of each residue in altering binding affinity.

Table 2: The parameters used in automated docking.

\begin{tabular}{ll}
\hline Parameter & Value \\
\hline Pop size & 50 \\
Crossover rate & 0.50 \\
Elitism & 7 \\
Maximum generation & 50000 \\
Mutation rate & 0.5 \\
Convergence & 1.000 \\
Site boundaries & $35 \AA$ \\
\hline
\end{tabular}

\subsection{Validation}

In this study, the validation was done through docking scores and the number of hydrogen bonds. The better binding affinity was indicated by more negative value of docking score and increased in the number of hydrogen bonds.

\section{RESULTS AND DISCUSSION}

\subsection{Crystal Structures Selection and Cleaning}

The crystal structure of polygalacturonase from Aspergillus niger (PGII) was selected from The Protein Data Bank (PDB) website with the access number of 1CZF. The selection was done based on the major applications in the fruit juice industry as reported in the literature.

Hydrogen atoms were added to the structure and the position of the hydrogen atom was optimized by molecular mechanics calculation to ensure their placement at the most favorable potential energy configuration. Hybridization of the whole structure was balanced by molecular mechanics calculations. The resultant structure is shown in Fig. 1.

\subsection{Analyzing PGII-1CZF Structure}

PGII folds into a right-handed parallel $\beta$-helical structure comprising 10 complete

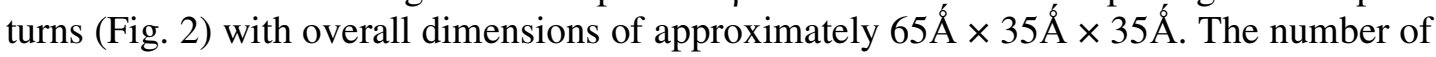
amino acids per turn varies from 22 to 39 , averaging 29 residues per turn. This variation is due to the diversity of lengths of the loops connecting the $\beta$-strands. The average rise per turn is $4.8 \AA$, a typical value for parallel $\beta$-helical structure and it is formed by four parallel $\beta$-sheets, named PB1, PB2a, PB2b, and PB3. In addition, the $\beta$-helix has a small $\alpha$-helix near the N-terminus, which shields the enzyme's hydrophobic core [8]. 


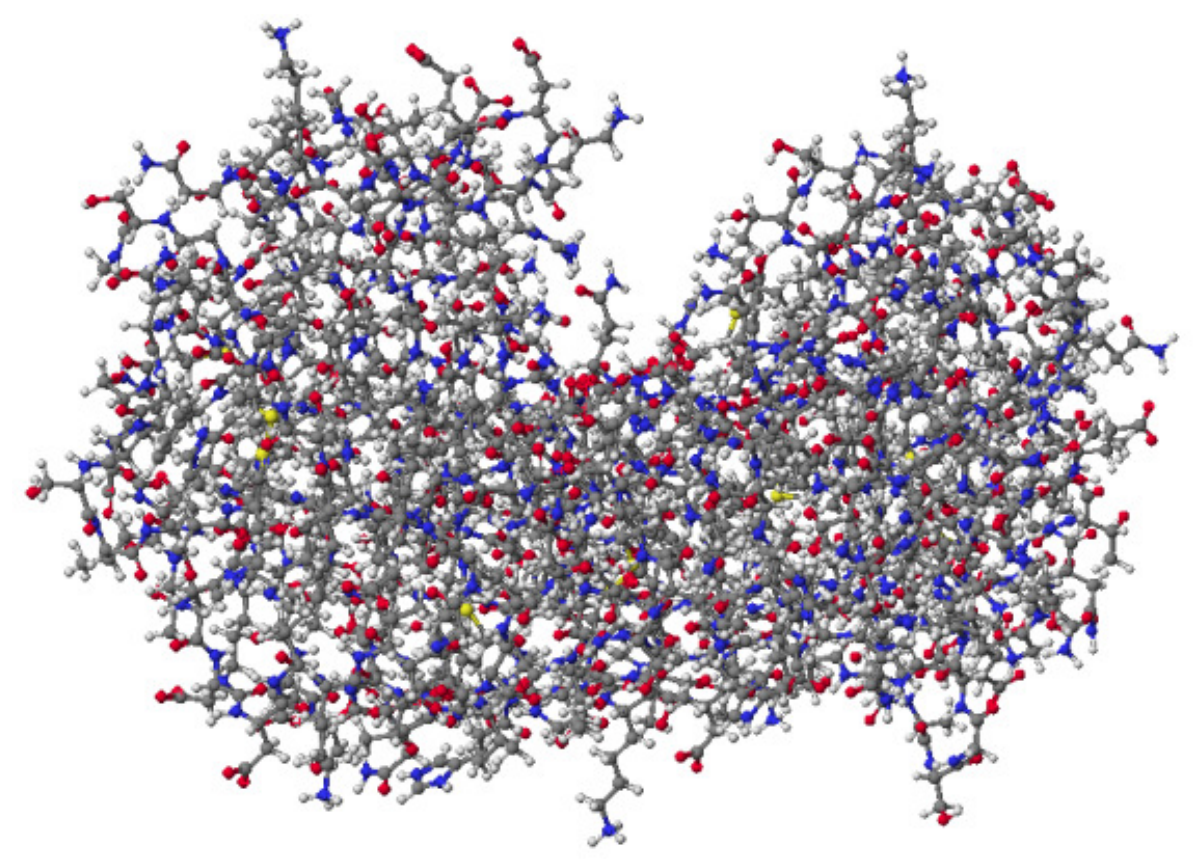

Fig. 1: Cleaned structure of polygalacturonase (PGII-1CZF).

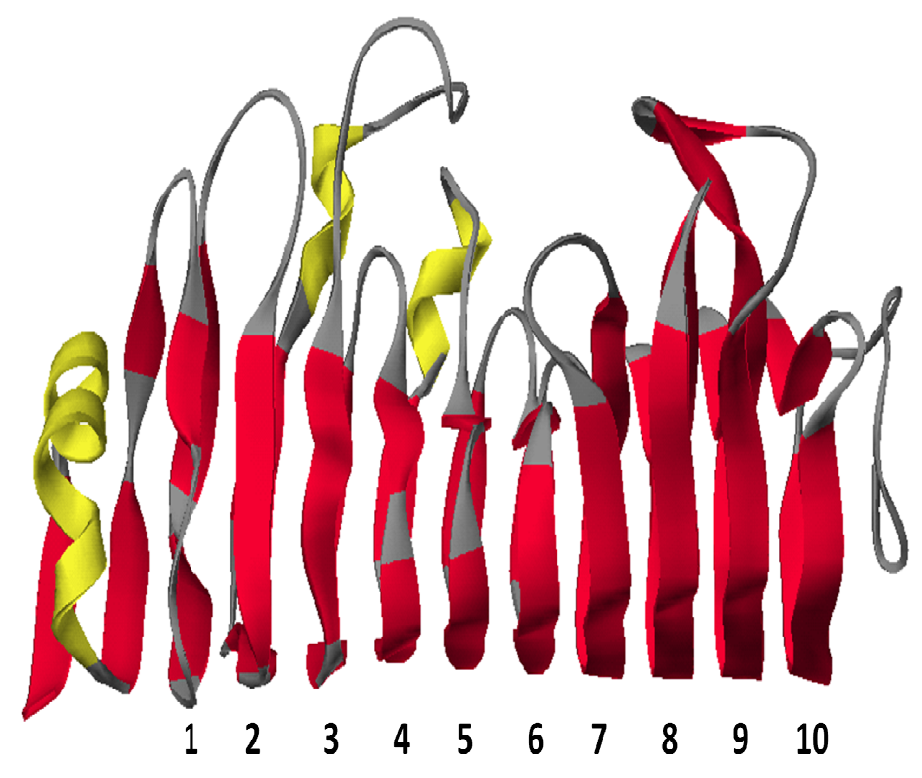

Fig. 2: Three dimensional structure of PGII-1CZF. Complete ten rung (number 1-10).

\subsection{Active Site Identification and Analysis}

The active site of PGII was characterized based on the information given in the literature because there is no ligand bound to this structure. The active residues are Asp180, Asp201, Asp202, Asn178, His223, Gly224, Gly229, Ser229, Arg256, Lys258 and Tyr291. They are conserved among polygalacturonase. The catalytic residues of this enzyme are aspartate group (Asp180, Asp201 and Asp202). 
For confirmation purpose of the PGII active site, it was compared with the polygalacturonase from Stereum purpureum (1KCC) associated with a ligand binds to the structure (Fig. 3). This method of confirmation is valid because both structures are almost same. Three basic residues of 1KCC are His195, Arg226, and Lys228 will interact with carboxyl group for enzymatic activity.

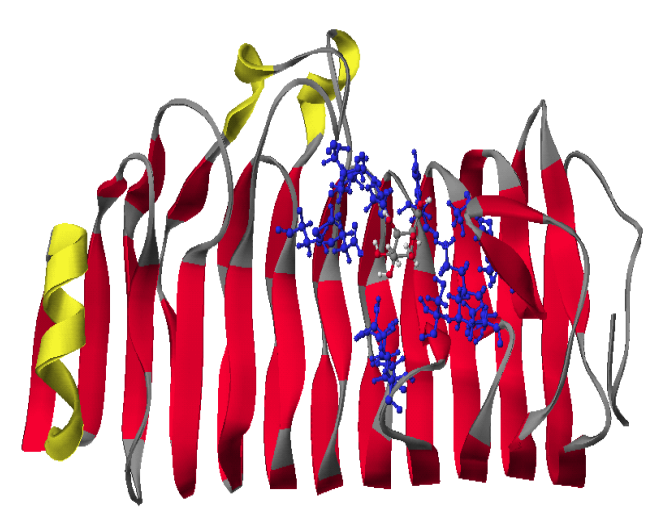

(a)

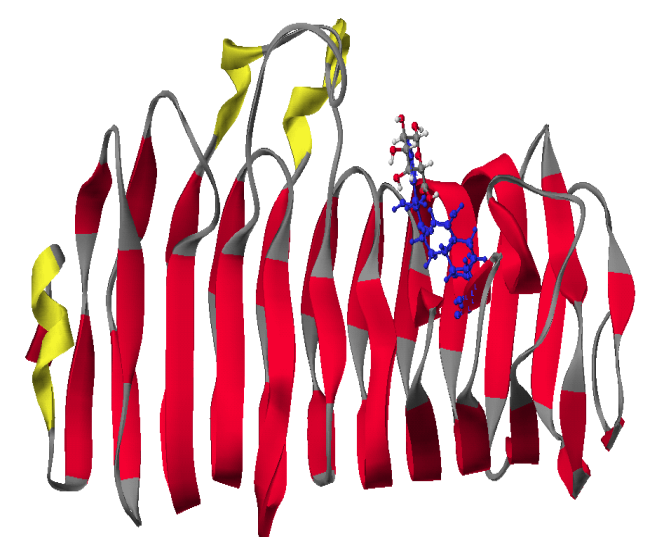

(b)

Fig. 3: Location of the ligand (GTR) in the structure; (a) GTR is docked in structure from Aspergillus niger (1CZF) (b) location of GTR in the structure from Stereum purpureum (1KCC).

The active site was also analyzed by creating an accessible surface (Fig. 4) of its region. The accessible surface was generated from the defined active site. Areas colored with mauve (purple-red) and blues are hydrophilic while the cream areas are hydrophobic. Mauve indicates hydrogen acceptor and blue indicates areas of hydrogen donors.

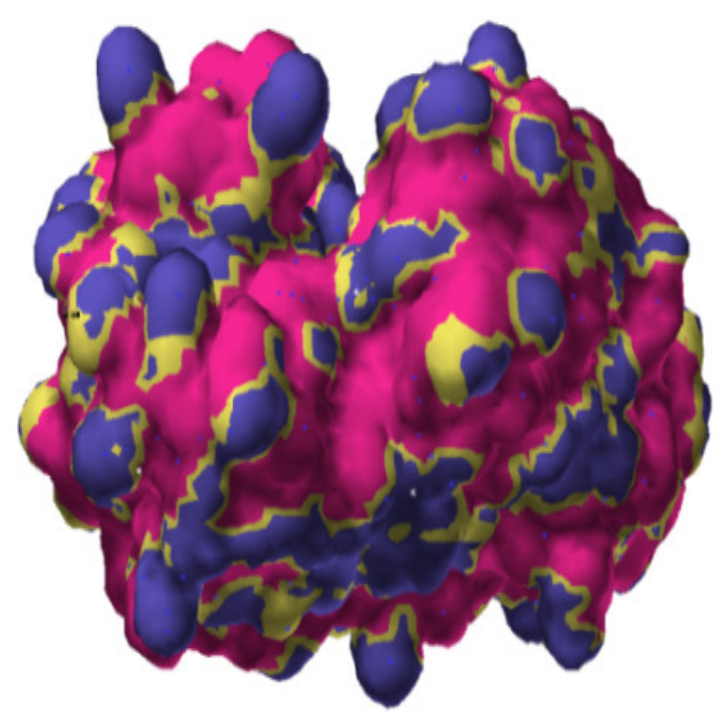

Fig. 4: Accessible surface of active site. 


\subsection{Mutation Analysis: Docking Score and Hydrogen Bonds}

Single point mutation was done to the structure of PGII-1CZF. The mutations were done to the residues at positions of 256 and 258 with R256Q and K258N, respectively. Mutation affects the formation and disruption of hydrogen bond between residues in the active site and ligand as well as the residues within the active site which has significant consequences on the ligand binding

The purpose of single point mutation in this work is to examine how the binding strength will be affected by this mutation. The mutation was done based on the experimental data that have been reported in literature. In this process, the lower docking score indicates the increase in binding strength. Moreover, the increasing number of hydrogen bonds also leads to stronger binding strength.

Table 3: Docking score.

\begin{tabular}{lll}
\hline Mutations & $\begin{array}{l}\text { Docking Score } \\
\text { (kcal/mole) }\end{array}$ & $\mathbf{K}_{\mathbf{M}}$ (units.mg ${ }^{-1}$ ) \\
\hline Wild-type & $-254.635 \pm 3.468$ & 0.15 \\
R256Q & $-220.021 \pm 1.513$ & 1.7 \\
K258N & $-253.271 \pm 6.048$ & 2.8 \\
\hline
\end{tabular}

Based on the literature review, none of the mutations showed the increased activity since the $\mathrm{Km}$ values is greater compared to the wild-type [8]. The docking scores obtained in our simualtions are reported in Table 3. The docking score for the mutations $\mathrm{R} 256 \mathrm{Q}$ and $\mathrm{K} 258 \mathrm{~N}$ ar found to be more positive, indicating less binding and lowering of enzyme activity. These results correlate very well qualitatively with the experimental $\mathrm{Km}$ values.

The residues, R256 (Arg256) and K258 (Lys258) are very crucial for the enzyme binding as they primarily involved in the interactions with the substrate. Thus, the mutation of the residues are expected to reduce the enzyme activity. Hence our simualtion results are consistent with the experimental results. However, further mutations has to be attenpted to increase the binding strength and hence the enzyme activity of polygalacturonase.

\section{CONCLUSION}

It is shown that the computer simulations can successfully reproduce the experiemtnal trends in the changes of the binding strength of polygalacturonase through mutation of residues in the active site region. Eventhough the identified active site and the trends in binding strengths compare very well with the available experimental results, further attempts through computer aided site directed mutation are needed to design new polygalacturonase enzymes with improved binding strength.

\section{REFERENCES}

[1] Pandey, A., \& Sumitra Ramachandran, 2006. General Introduction in Enzyme Technology. A. Pandey, C. Webb, \& C. R. Larroche. Asiatech, New Delhi, pp: 1-10. 
[2] Sandra, A., \& Hari, K., 2006. General Properties of Enzymes in Enzyme Technology. A. Pandey, C. Webb, \& C. R. Larroche. Asiatech, New Delhi, pp: 11-36.

[3] Nikolic, M. V., \& Mojovic, L., 2007. Hydrolysis of apple pectin by the coordinated activity of pectic enzymes. Food Chemistry, 101:1-9.

[4] Cho, S. W., Lee, S., \& Shin, W. 2001. The X-ray sturucture of Aspergillus aculeatus polyglacturonase and a modeled Structure of the polygalacturonase-octagalacturonase complex. Journal of Molecular Biology, 311:863-878.

[5] Fawole, O.B. \& Ofunda S.A. 2003. Some factors affecting production of pectic enzymes by Aspergillus niger. International Biodeterioration \& Biodegradation, 52:223-227.

[6] Leach, A., 2001. Molecular Modelling:Principles and Applications. England: Pearson.

[7] van Santen Y, Benen J. A., Schröter K. H., Kalk K. H., Armand S., \& Visser J., Dijkstra B. W., 1999. 1.68-A Crystal Structure of endopolygalacturonase II from Aspergillus niger and Identification of Site Residues by Site-directed Mutagenesis. Journal of Biological Chemistry, 274:30474-30480.

[8] Pagès S., Heijne W. H., Kester H. C., Visser J., \& Benen J. A., 2000. Subsite mapping of Aspergillus niger Polygalacturonase II by site directed mutagenesis. The Journal of Biological Chemistry, 275: 29348-29353. 